\title{
Odešla významná osobnost českého národního života
}

\author{
Ivo Pospíšil (Brno)
}

Dne 19. 6. 2016 ve věku 89 let zemřel PhDr. František Kautman, CSc. K jeho 85. narozeninám se v Národní knihovně ČR konal speciální seminář a jeho publikační výstup na počest tehdejšího jubilanta Na trnitých cestách života a tvorby F. Kautman - nehledě na značné potíže s vydáním - přece jen uviděl (vyšel 2015). Pro Slavica litteraria jsme vybrali něco z toho, co Kautmana charakterizuje jako literáta a literárního vědce. ${ }^{1}$

František Kautman byl novinář, nakladatelský a časopisecký redaktor, literární vědec a kritik, překladatel, editor, básník a prozaik, kulturní činitel, signatář Charty 77, člen International Dostoyevsky Society, člen společnosti F. X. Šaldy, spoluzakladatel a tajemník Klubu osvobozeného samizdatu. Narodil se 8. 1. 1927 v Českých Budějovicích. Dominantou jeho uvažování byly existenciální problémy člověka v sevření dějin, samota a úzkost. Tyto okruhy se objevovaly jak v jeho vědeckých pracích, tak v jeho literární tvorbě. Když jsem psal jeho heslo pro druhý díl známého slovníku², ptal jsem se na židovství. Sám podle vlastních slov nebyl židovského původu, židovská tematika se však v jeho díle ztlumeně reflektovala, ale nikoli výlučně v rovině náboženské nebo etnické, spíše jako odrazová plocha obecnějších témat. Židovství jako ghetto nebo několikeré ghetto (etnické, náboženské, česko-německé) je emblémem obecně lidské osamělosti a z toho plynoucí úzkosti. ${ }^{3}$

1 Bibliografie Františka Kautmana se nachází ve svazku Na trnitých cestách života a tvorby. Sbornik príspěvki̊ ze sympozia pořádaného u př́ležitosti životního jubilea Františka Kautmana. (Praha, 25. 1. 2012, Národní knihovna České republiky). Sestavily Miluša Bubeníková a Radka Hř́ibková. Praha: Národní knihovna ČR Slovanská knihovna, 2015, pod názvem Bibliografie prací Františka Kautmana (1949-2013), Bibliografie prací o Františku Kautmanovi a jeho dilech (1950-2013) a Ediční poznámka k bibliografii prací Františka Kautmana, kterou napsala sestavovatelka bibliografie Miluša Bubeníková. Asi leccos v bibliografii F. K. i v kritických reflexích jeho díla chybí a nejen to, o čem píše sestavovatelka, jejíz práci nutno vrcholně ocenit; ze svých četných př́spěvků $\mathrm{k}$ dílu F. K., z nichž mnohé tu jsou uvedeny, tu chybějí dvě mé zahraniční publikace o F. K.: Osobnost Františka Kautmana a jeho Román pro tebe. Slavica Occidentalis (Poznań), 2002, s. 145154; a Roždenije srednej evropejskoj poetiki (F. Kautman - O. Filip - J. Zogata - M. Viewegh). In: Vzaimodejstvije literatur v mirovom literaturnom processe. Problemy teoretičeskoj i istoričeskoj poetiki. Materialy $\mathrm{X}$ meždunarodnoj naučnoj konferencii v dvuch častjach. Grodno: Meždunarodnaja associacij aprepodavatele jrusskogo jazyka i literatury, Učreždenije obrazovanija „Grodnenskij Gosudarstvennyj Universitet imeni Janki Kupaly, 2005, čast' 1, s. 79-91.

2 Heslo Kautman, František (8. 1. 1927 v Českých Budějovicích). In: MIKULÁŠEK, Alexej - ŠVÁBOVÁ, Jana - SCHULZ, Antonín B. a kol.: Literatura s hvězdou Davidovou 2. Slovniková přiručka $k$ dĕjinám česko-židovských a česko-židovsko-nèmeckých literárnich vztahů 19. a 20. století. Praha: Votobia, 2002, s. 42-48.

3 V př́tomném nekrologu bylo využito textu našich četných recenzí a studií, na něž tu odkazujeme. 
Narodil se v učitelské rodině, jeho otec byl vášnivým čtenářem, majitelem bohaté knihovny, matka Stanislava (1902-1982) vystudovala hudební školu (klavír a zpěv), psala do novin, vydala pět románů, pět knih pro děti a tři loutkové hry. Sestra Stanislava, provdaná Dolinová (1924-1981), byla také novinářka a spisovatelka. Do obecné školy (1932-1937) chodil v Trhových Svinech a v Českých Budějovicích, reálku (později reálné gymnázium) vystudoval v Českých Budějovicích (maturoval 1945), Vysokou školu politickou a sociální v Praze (1945-1949) ukončil druhou státní zkouškou. V letech 1949-1952 byl šéfredaktorem nakladatelství Československý spisovatel, pak studoval na Literárním institutu Maxima Gorkého v Moskvě a tamtéž konal vědeckou aspiranturu (1952-1957), kterou ukončil obhajobou kandidátské disertační práce Razvitije socialističeskogo realizma v poezii Stanislava K. Nejmana (vědecká hodnost CSc. mu byla udělena týž rok). Na základě disertace mu byl roku 1968 udělen na Filozofické fakultě Karlovy univerzity doktorát filozofie. Po návratu do Československa (1957) vedl dva roky literární rubriku časopisu Kultura, pak pracoval jako odborný dokumentátor v Encyklopedickém institutu ČSAV (1959-1961) a posléze byl vědeckým pracovníkem Ústavu pro českou literaturu ČSAV (1961-1971). Po propuštění ze zaměstnání z politických důvodů byl dva roky bez práce a pak byl krátce prodavačem v podniku Klenoty-starožitnosti (1973-1974). Od roku 1974 v invalidním důchodu. V letech tzv. normalizace se podílel na organizování a vydávání českého samizdatu. Spolu s Janem Vladislavem se stal zakladatelem samizdatového časopisu Kritický sborník (1981-1989). Jeho studie vycházely v různých samizdatových a exilových edicích (Listy, Svědectví, Obrys, Proměny). V roce 1977 byl jedním z prvních signatářů Charty 77. Stal se členem redakční rady Spisů T. G. Masaryka a Masarykova sborníku. Po převratu roku 1989 se věnoval přednáškové činnosti, vědecké a literární práci a publicistice, vydával své dílo editované do té doby jen samizdatově. Publikoval v periodikách Lidové noviny, Občanský deník, Práce, Prostor, Lidová demokracie, Nové knihy, Kritický sborník, Labyrint, Literární noviny, Listy, Tvorba, Česká politika, Svobodný zítřek, Svět a divadlo, Ateliér, Divadelní noviny, Nová Př́tomnost, Germanoslavica, Informační bulletin ČAR aj.

Židovská tematika nemá v Kautmanově díle výlučné postavení, spíše - jak již řečeno - plní funkci odrazové plochy dominantních existenciálních okruhů. Nejpozoruhodnější a nejoriginálněǰši je to, že Kautman organicky spojil ruský, židovský, český a německý okruh. Kromě první větší literárněvědné práce o socialistickém realismu v díle S. K. Neumanna je jeho další zájem soustř̌eděn na ruskou literaturu, literární kritiku a německy psanou tvorbu. Od šedesátých let je v Kautmanově tvorbě patrný zájem o obecné otázky lidského bytí. Boje o Dostojevského (1966) jsou úspěšným pokusem o docenění díla ruského génia, který kladl zásadní otázky: Dostojevským léčí Kautman i svou původně jednostrannou ideologickou orientaci čtyřicátých a padesátých let. Od šedesátých let minulého století se Kautmanovo myšlení pohybuje v osobnostních a tematických řetězcích: charakteristické jsou jeho spřažené triptychy Dostojevskij, Kafka, Hostovský nebo Masaryk, Šalda, Patočka. Spojení Dostojevského, jemuž bývají - pravděpodobně ne zcela neprávem - vytýkány antisemitské sklony, s židovskými autory Kafkou a Hostovským, přičemž oba patřili zjevně $\mathrm{k}$ asimilujícím se Židům, jež však nepřestávali cítit zhoubnou sílu samoty a úzkosti, patří k zdánlivým paradoxům této problematiky, i když inspirace Dostojevským je u obou autorů zjevná. 
Kautman reprezentuje typ badatele, který ve vyčerpávající činnosti vytváří duchovní most mezi zdánlivě protilehlými břehy evropského myšlení. Dostojevskij vycítil jako dominantu nadcházejícího věku samotu, úzkost a strach: Kafkova orientace na „nemocnou“ ruskou literaturu, na Gogola, Suchovo-Kobylina, Dostojevského a později „ruské“ postupy, které užívá Hostovský, jsou pro Kautmanovy zájmové okruhy typické. Nejpříznačnější součástí samoty, úzkosti a smrti je láska, sexuální a erotická rovina lidského života - těmto tematickým clusterům věnuje Kautman maximální pozornost nejen ve svých literárněvědných pracích, ale také v beletrii. Do knihy Svět Franze Kafky (první oficiální vydání TORST 1990; druhé pod názvem Franz Kafka, Rozmluvy, Praha, 1992; třetí pod týmž názvem Academia, 1996; německy Die Welt Franz Kafkas, Academia, 1996) umístil speciální kapitolu Sexuální tragédie, jakousi parafrázi proslulé Kallinikovovy knihy Tragédie sexuálni (o Lvu Tolstém, Praha, 1931). I když Kautman nestojí na ortodoxním freudovském stanovisku, tato kapitola spolu s pasážemi o moci patří v knize o Kafkovi k nejlepším. „Nikdo nesnesl a nikdo nesnese tolik argumentů proti Kafkovu dilu, jako snesl sám jeho autor (proto je tak lehké je kritizovat). Nejsem světlem. Jen jsem se zapletl ve vlastním trní. Jsem slepá ulička, řekl Kafka Janouchovi. Do slepé uličky však ve XX. století zabloudilo celé lidstvo, proto tak neočekávaně Kafku našlo a poznalo se v něm. Kafkovské situace se opakuji $v$ řetězových reakcich. Se seismografickou citlivosti zaznamenal Kafka absurdni zákonitosti budoucího vývoje. Sám by měl asi malou radost z toho, že byl tak přesný. Tenhle ,Ďáblìv kolotoč bychom měli před očima, $i$ kdyby Kafkovo dilo bylo zničeno nebo kdyby vůbec nebylo vzniklo. Protože je máme, můžeme lépe pochopit sami sebe. Čím hlubši a bezohlednějši bude toto pochopeni, tím bliže budeme $k$ východisku, které by mohlo znamenat naději. Snad." Těmito slovy se Kautmanova kniha o Kafkovi uzavírá.

K Dostojevskému se autor vrací jednak v překladu Dopisů (1966), jednak v knize F. M. Dostojevskij - věčný problém člověka (samizdat 1976, oficiálně 1992). Kautman Dostojevského nemodernizuje, ale současně vědomě vytváří jeho spojitost s 20. stoletím a zvláště s Kafkou a moderní existenciální prózou. Podstatným př́ínosem literárního vědce Kautmana je minuciózní analýza poetiky zmíněných autorů, jejich loci communes (podzemní člověk, hmyz, fetišismus nožky u Dostojevského, hudba, zvuk, hlas zvonku, brána, dveře, voda apod. u Kafky). V monografii o Egonu Hostovském zdůrazňuje jeho židovský původ a to, jak rodinu tragicky postihl holokaust. Přitom však neopomene - podobně jako v případě Kafkově - zdůraznit, že „Hostovského nelze opatřit žádnou světonázorovou ani směrovou nálepkou, také nikdy nepř́slušel $k$ žádné politické straně a nebyl ortodoxním vyznavačem žádné náboženské konfese." I když se židovství v jeho díle reflektuje jako bolestný úder živelného českého antisemitismu, záběr Hostovského je širší: je to touha spojovat protiklady, nacházet skutečný život a vyvracet ideologická schémata. Proto Kautman v jeho díle ukazuje na přátelství lidí ideově protichůdných, na rozpor lidské a ideologické dimenze. V triptychu Masaryk, Šalda, Patočka (1990) dopisovaném na počátku sovětské perestrojky prezentuje Kautman tuto představu více než důrazně: „Ideologický krunýr musí být proražen, ideologie musi být postavena mimo základni globálni problémy lidského osudu [...] Jen nesmirné etické vypěti statisiců myslicich hlav a planoucích srdci celého světa, které prènonaji zkostnatèlé ideologické šablony (odideologizovat lidstvo ve smyslu likvidace ideologického fanatismu je stejně nezbytným hygienickým úkolem jako odvšivení) a spoji se k řě̌eni základnich problémů 
lidstva v linii etika - ekologie by mohlo lidstvu dát šanci na přežití." Proti svým původně ideologicky motivovaným koncepcím čtyřicátých a padesátých let staví Kautman od šedesátých let kritické myšlení a skepsi: na počátku sovětské perestrojky se místy znovu vrací nadšení, které se emotivně a pateticky staví proti ideologii, jako se před tím stavělo za ni. Ideologie nelze vykázat ani zakázat, jsou legitimním průvodcem člověka a společnosti, lze jim však vzít vládu nad lidskými osudy: nejnebezpečnějším podporovatelem ideologií je právě patos, emoce, nadšení: ostatně i etika a ekologie mají svou ideologii...

Nehledě na tyto kritizovatelné aspekty je Kautmanovi vždy vlastní původnost, citlivost a skepse: objevuje zajímavé momenty v tvorbě $\mathrm{S}$. K. Neumanna, prezentuje vlastní přečtení Dostojevského, Kafky a Hostovského, Masaryka, Šaldy a Patočky, objevuje tehdy nově polohy existenciální prózy, rozehrává zpovědní koncert hříchu a očištění, nachází moderní dimenze ruské revolučně demokratické kritiky (v knize $K$ typologii literární kritiky a literárni vědy, publ. 1996) a v šedesátých letech objevuje pro nás filologickou hermeneutiku (tamtéž, ve studii Hermeneutika a interpretace, 1969).

Kautman je spíše prozaik, psal však také poezii: sbírka Opilý satelit vyšla roku 1966, samizdatové vydání šesti básnických sbírek z let 1965-1981 Melodie na jedné struně je z roku 1981. Je v ní výrazně přítomna dominanta, která je vlastní autorovým literárněvědným pracím a především prózám jeho oblíbených autorů: hřích a vykoupení, sebezpytující výčitky svědomí, mezigenerační bariéra, poruchy komunikace, samota i erotická křeč připomínající Kafku a Hostovského, zmarňování ideálů. Patrně nejpregnantněji však tyto okruhy vyjadřuje próza, mj. povídky Nádhera rovnováhy (1969), snad vůbec nejlepší Kautmanova prozaická práce a pravděpodobně stěžejní dílo české literatury šedesátých let. Zejména povídka Já a má dcera (1963) v koncentrované podobě vyjadřuje potřebu očisty i mezigeneračního porozumění, nehledě na tragičnost vyústění. Touha po oproštění a očistě je i v „oddechové“ próze Jak jsme s Jackem hledali svobodu (pův. 1981; vyd. 1995) hledající základní kategorie lidského bytí ve spojení s přírodou a samozřejmostí každodennosti. Teoretici románu snad ještě více ocenili Mrtvé rameno (pův. 1977; vyd. 1992) a zejména silně autobiografický Prolog k románu (pův. 1979; vyd. 1992) s prvky metatextu a ohlasu ruské literatury 19. století.

Tvorba židovských autorů i pocit židovské vykořeněnosti jsou ponornou řekou, která obecně existenciální polohy u Kautmana propojuje: někde je to silné a konkrétní (Kafka, Hostovský), někde jen náznakové (vlastní próza), jinde se židovství stává emblémem, symbolem obecné platnosti, duchovním ghettem. Zdá se, jako by autor židovskou tematiku záměrně tlačil do obecné, scelující polohy, jako by ji chtěl obalit co největším množstvím jiných odkazů a bočních linií, ale ona se často nečekaně prostřihne i tou nejpevnější slovesnou tkání. V tomto napětí a filozofické a psychologické oscilaci je Kautmanovo dílo snad jednou z nejpozoruhodnějších reflexí židovské tematiky v české slovesné kultuře druhé poloviny 20. století. O F. Kautmanovi jsem poměrně často psal a byl mi vždy blízký (viz dále). ${ }^{4}$

4 Viz naše recenze a studie o F. K.: Metody, přístupy a typy literárni vědy (František Kautman: K typologii literární kritiky a literární vědy). SPFFBU, XLVI, D 44, 1997, s. 161-164; Kulturní zápisník Literatura a citlivost (F. Kautman). Univerzitní noviny 2001, č. 12, s. 51-54; Kautman, František (8. 1. 1927 v Českých Budějovicích). Heslo. In: MIKULÁŠEK, Alexej - ŠVÁBOVÁ, Jana - SCHULZ, Antonín B. a kol.: Literatura s hvězdou 
Na podstatné otázky národního bytí odpovídá v knize, jež vznikala od sedmdesátých let minulého století, ale byla publikována nedávno - O českou národni identitu. ${ }^{5}$ Jeho výklad je v podstatě chronologický, kauzálně provázaný a nejzajímavější je to, že vznikl v sedmdesátých letech 20. století, kdy byl autor odstřižen od publikačních možností (až do roku 1989), podílel se na vydávání českého samizdatu, stal se členem mezinárodní Dostoevsky Society. Kautmanova tvorba je obsáhlá a obsažná - a to se ještě postupem času s úžasnou silou projeví. Především je František Kautman člověkem, jenž vystupuje nejméně v dvojí podobě, tedy jako umělec, básník, prozaik a esejista, básník v širokém slova smyslu německého „Dichter“, ale i jako literární kritik, historik a teoretik; dokáže tyto své tváře nenásilně propojovat, aniž by je přímo spojoval, a rozřed’oval tak jejich jedinečnost. Kromě fascinace rustvím a Ruskem je Kautman také Středoevropan. V knize Středni Evropa a Slované (2006) jsem ho zařadil mezi Středoevropany volbou: je jazykově, kulturně i mentálně ukotven v tomto areálu; snad s výjimkou Uher; jeho střední Evropa je především jevem německo-slovansko-židovským, a tak také Františka Kautmana chápeme. Současně však platí, že střední Evropa, která byla tolikrát odsouvána a zrazována, není uzavřená a je otevřená nejen na Západ, ale i na Východ, tedy především k Rusku; mám kupodivu na mysli i geopolitické faktory, i když Rusové na toto teritorium rozhodně nevstoupili poprvé roku 1945 ani roku 1968, ale jde nám především o jevy kulturní

Davidovou 2. Slovníková příručka k dějinám česko-židovských a česko-židovsko-německých literárních vztahů 19. a 20. století. Praha: Votobia, 2002, s. 42-48; Detail jako emblém doby. František Kautman: O literatuře a jejich tvůrcích. Studie, úvahy a stati z let 1977-1989. Slovak Review, A Review of World Literature Research, vol. 11/2002, No. 2, s. 174-178. Osobnost Františka Kautmana a jeho Román pro tebe. Slavica Occidentalis (Poznań), 2002, s. 145-154; Živá bible (František Kautman: O smyslu oběti. Biblické reflexe). Slavica litteraria, X 7, 2004, s. 138-139; Odna srednejevropejskaja sud'ba (František Kautman kak literaturoved i belletrist). In: Comparative Cultural Studies in Central Europe. Ed. Ivo Pospíšil (Brno) - Michael Moser (Wien). Brno: Ústav slavistiky Filozofické fakulty Masarykovy univerzity v Brně, 2004, s. 175-191; Živá bible (František Kautman: O smyslu oběti. Biblické reflexe). KAM - př́loha, 2004, č. 6, s. VIII-IX; Prokletí a krása Dostojevského (F. Kautman: Dostojevskij - věčný problém člověka). KAM - př́loha 2005, č. 5, s. 9-10; Roždenije srednejevropejskoj poetiki (F. Kautman - O. Filip - J. Zogata - M. Viewegh). In: Vzaimodejstvije literatur v mirovom literaturnom processe. Problemy teoretičeskoj i istoričeskoj poetiki. Materialy X meždunarodnoj naučnoj konferencii v dvuch častjach. Grodno: Meždunarodnaja associacija prepodavatelej russkogo jazyka i literatury, Učreždenije obrazovanija, Grodnenskij Gosudarstvennyj Universitet imeni Janki Kupaly, 2005, čast' 1, s. 79-91; Franz Kafka a Julie Wohryzková: neznámý dopis. František Kautman: Kafka a Julie (Památník národního písemnictví, Praha 2008, 21 s.) http://www.phil.muni.cz/journals/proudy/ PROUDY_PHILOLOGIE.htm; Dílo Františka Kautmana jako metodologické přemostění. In: LORENCOVÁ, Ivana - NOVOTNÝ, Michal (eds.): Věda a technika v Československu v 60. letech 20. století. Praha: Národní technické muzeum, 2011; František Kautman: Alternativy. Proudy 2014, 2. http://www.phil.muni.cz/journal/ proudy/filologie/recenze/2014/2/pospisil_kautman_alternativy.php\#articleBegin; Plynuti a ukotveni v díle Františka Kautmana. In: Na trnitých cestách života a tvorby. Sborník příspěvků ze sympozia pořádaného u příležitosti životního jubilea Františka Kautmana. (Praha, 25. 1. 2012, Národní knihovna České republiky). Sestavily Miluša Bubeníková a Radka Hříbková. Praha: Národní knihovna ČR - Slovanská knihovna, 2015, s. 15-34; Na trnitých cestách života a tvorby. Sbornik přispěvkư ze sympozia pořádaného u př́ležitosti životniho jubilea Františka Kautmana (Praha, 25. 1.2012, Národni knihovna České republiky). Proudy 2015, 1. http://www.phil.muni.cz/journal/proudy/filologie/recenze/2015/1/pospisil_na_trnitych_cestach_ zivota_a_tvorby.php\#articleBegin. O českou národní identitu. František Kautman: $O$ českou národni identitu. Pulchra, edice Testis, Praha 2015. ISBN 978-80-87377-62-8. Proudy 2015, 1.http://www.phil.muni.cz/ journal/proudy/filologie/recenze/2015/1/pospisil_o_ceskou_narodni_identitu.php\#articleBegin.

5 KAUTMAN, František: $O$ českou národni identitu. Praha: Pulchra, 2015. 
povahy (ty ostatně představuje i armáda, a to v různých významech), táhnoucí se od Josefa Dobrovského a jeho poněkud tajemného moskevského pobytu.

I když Kautmanova kniha vznikla v podstatě před čtyřiceti lety, nemohl se autor alespoň v závěru autor v postskriptu vyjádřit $\mathrm{k}$ současné situaci: „Je zřejmé, že naše polistopadová demokracie funguje tak, jako by chtěla svět přesvědčit, že si vládnout neumíme [...] Ač nemáme výrazné politické osobnosti, žijeme iluzí, že vedoucí funkce je z nich udèlá. Tak se vždycky formovaly autoritativni režimy [...] Náš polistopadový vývoj ukázal, že v tomto směru jsme na sobě př́liš nezapracovali. “6 Kautmanova kniha by mohla být učebnicí českého politického myšlení, českých dějin i české praktické politiky - kdyby našel své čtenáře, kteří by byli na její výši - a takových je čím dál méně.

Poznal jsem dr. Kautmana až v devadesátých letech minulého století a po čase jsme se sblížili, i když naše generace jsou značně vzdálené, životní zkušenosti různé, názory a politické postoje nikoli vždy identické, životní dráhy taktéž, ale společný jsme měli kritický pohled na lidskou a společenskou realitu dneška a sdíleli jsme obavy o osudy tohoto světa, tak, jak jej známe, o lidskou kulturu obecně a naši zvláště. Samozřejmě by se našly ještě jiné spojitosti: literatura, zvláště česká, ruská a německá, literární věda a kritika. Cenil jsem si Kautmanovy stati o mých pracích. ${ }^{7}$ Nepravidelně jsme scházeli v Praze v kavárně Slavia, která byla dr. Kautmanovi snadněji dostupná, do Brna se již vypravit nemohl. ${ }^{8}$ Naše rozhovory se týkaly souboru jeho osobitých deníků, inspirovaných Dostojevským a dalšími - Bilance, jejichž vydání se snad stále plánuje, jak aspoň dokládá i příspěvek Jana Šulce v zmíněném jubilejním sborníku z roku 2015, ale hlavně současnosti: už jsme se nevraceli k životní dráze Kautmanově, k omylům jeho mládí - kdo se někdy nemýlil? - $\mathrm{k}$ jeho disidentství a působení v samizdatu - o tom jistě napiší jiní. Pro mě zůstává zajímavou i jeho mladistvá činnost šéfredaktora Československého spisovatele, jeho studium v SSSR, jeho disertace o S. K. Neumannovi v ruštině i její česká varianta, tak jeho studie o Kafkovi a jeho význam v organizaci proslulé liblické konference a jejího publikačního výstupu, který nyní znovu pročítám, jeho jasnozřivá studie o hermeneutice z roku 1969; i když nesouhlasím s jeho novější totální negací ideologie, rozumím mu, vím, že to vyplývá z jeho životní cesty, která však byla vždy podle mého názoru hluboká a poctivá i v jejích křivolakostech a radikálních počátcích, k nimž se Kautman nejednou kriticky vracel. Jeho síla i jeho omyly vyplývaly organicky z cesty a historické zkušenosti českého společenského myšlení, jeho jádra i krajností. Kautmanovy omyly a jejich pozdější reflexe jsou pro nás všechny možná důležitější než pravdy těch, kteří měli a mají pravdu vždy a vždy jinou a za všech okolností rádi hráli a hrají dvojjedinou roli soudců i katů. Ostatně budoucnost, možná i docela blízká, ukáže.

6 Ibidem, s. 605.

7 KAUTMAN, František: Genologické a metodologické úvahy (Poznámky ke knize I. Pospišila Genologie a proměny literatury, Brno 1998). Opera Slavica 10, 2000, č. 1, s. 10-21.

$8 \mathrm{~V}$ posledních takřka již desetiletích jsem navázal podobně neformální, nepragmatické vztahy s řadou starších kolegů, mj. s prof. Slavomírem Wollmanem, prof. Zdeňkem Mathauserem, prof. Antonínem Měštanem, prof. Andrejem Červeňákem, abych jmenoval jen ty zvěčnělé. Přátelství dr. Kautmana si cením podobně. 
Na vlastní přání byl František Kautman pohřben v tichosti a bez obřadu zpopelněn. Jeho přítelkyně dr. Libuše Brodová, jejíž životní osud a osud její rodiny by si sám zasloužil samostatnou pozornost, však dala udělat běžné parte, které mi poslala. Je uvedeno citátem z V. M. Krameria: Žádná smrt nemůže být zlá, které predcházi dobrý život.

E-mail: ivo.pospisil@phil.muni.cz 
